\title{
Production of Bacillus thuringiensis based biopesticide formulation using starch industry wastewater (SIW) as substrate: A techno-economic evaluation
}

\author{
Lalit R. Kumar, Adama Ndao, Jose Valero, R.D. Tyagi * \\ INRS Eau, Terre et Environnement, 490, rue de la Couronne, Québec G1K 9A9, Canada
}

\section{ARTICLE INFO}

\section{Keywords:}

Biopesticide

Bacillus thuringiensis

Starch industry wastewater (SIW)

Economic evaluation

Profitability analysis

\begin{abstract}
A B S T R A C T
In this study, cost simulation was made to produce Bacillus thuriengiensis based biopesticide formulation using starch industry wastewater (SIW) as substrate. The results obtained at pilot plant (2000L capacity fermenter) were used for cost simulation of the process. The unit production cost for annual production of $5 \mathrm{million} \mathrm{L}$ of formulated biopesticide (20.2 Billion International Units (BIU)/L) was estimated to be $\$ 2.54 / \mathrm{L}$, which is competitive to chemical pesticides. The techno-economic evaluation revealed that the profitability of the biopesticide manufacturing process was sensitive to the plant capacity and selling price of the biopesticide. The manufacturer should target 5 million L annual plant capacity and selling price of $\$ 15 / \mathrm{L}$ for payback period to be less than 5 years. The process serves many advantages (1) alternate disposal or bio-valorisation of industry wastewater and (2) use of industry wastewater as inexpensive carbon source reducing cost of raw materials for fermentation.
\end{abstract}

\section{Introduction}

The significant population growth and industrialization has resulted in indiscriminate use of chemical pesticides to protect crops for high productivity. The consequences of using chemical pesticides are pollution of groundwater, crops, and environmental degradation (Marrone, 1999). Despite these drawbacks, the use of chemical pesticides is still relevant. Purchase price and ease of use are all plausible explanation. However, there are alternatives such as biopesticides based on Bacillus thuringiensis (Bt) type microorganisms, with endotoxin protein crystals which are lethal to many pests of Lepidoptera, Coleoptera and Diptera. Bt-based biopesticides occupy $97 \%$ of the world's biopesticide market (Cannon, 1993; Melo et al., 2016; Osman et al., 2015; Rodríguez et al., 2019; Sayed and Behle, 2017). Bacillus thuringiensis produces protein crystals made up of delta endotoxin, which bind to the receptors of the larvae's epithelial cells (Elleuch et al., 2016). The epithelial cells are thus destabilized by the creation of transmembrane pores in the cell membrane. The integrity of the epithelial cells is thus affected, leading to paralysis of the larvae's digestive system and the cessation of feeding. At the same time, viable spores produced during the stationary phase of bacterial growth will germinate in the mid gut of the budworm and produce other Bt cells and protein crystals. Proliferation of the bacterium will cause septicemia in larvae and death (Dang Vu et al., 2009).

However, a biological pesticide is effective only if it has a potential major impact on the target pest, market penetration, proper performance under variable field conditions, cost effectiveness and satisfactory end-user feedback (Copping, 1998). Bt is easily grown on synthetic medium. The use of a semi-synthetic medium such as soybean ensures intake of essential and basic nutrients for optimal growth and synthesis of secondary metabolites by the bacteria (Zouari and Jaoua, 1999). However, the inherent cost of the commercial medium for fermentation hinders biopesticide's competitiveness against chemical pesticides and also constitutes an obstacle to commercialization in less developed countries. Thus, the stream of the food waste industry or sewage treatment plants are alternatives to synthetic products (Ballardo et al., 2016,2017). It was found that the protein crystals from complex substrate (such as municipal or industrial sludges) are more lethal than those of easily assimilated substrate media (synthetic) (Azmi et al., 2015; Schnepf et al., 1998). Wastewater sludge has been successfully used as a raw material for Bt biopesticide production with lower process costs (Brar et al., 2005, 2006; Yezza et al., 2006,2004). In INRS research group, Bt-based biopesticide has been produced using starch industry wastewater (SIW) as it is rich in carbon and nitrogen

\footnotetext{
* Corresponding author.

Email address: Rd.tyagi@ete.inrs.ca (R.D. Tyagi)
} 


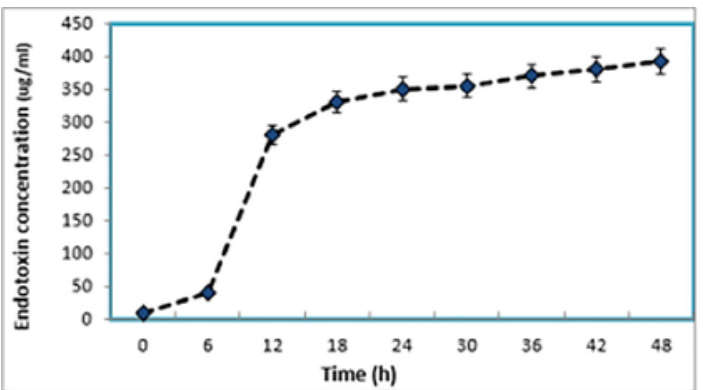

(a)

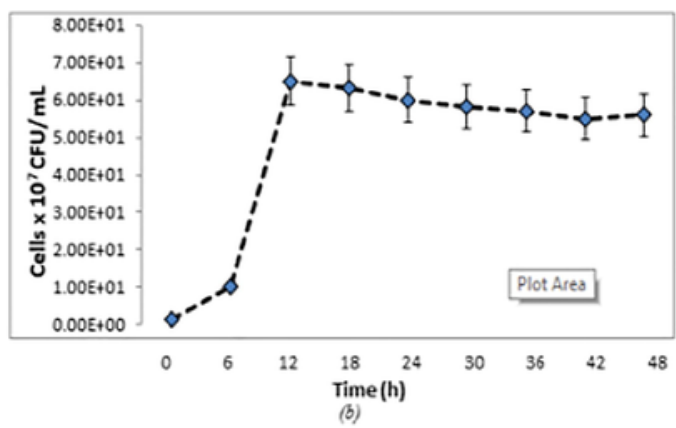

(b)

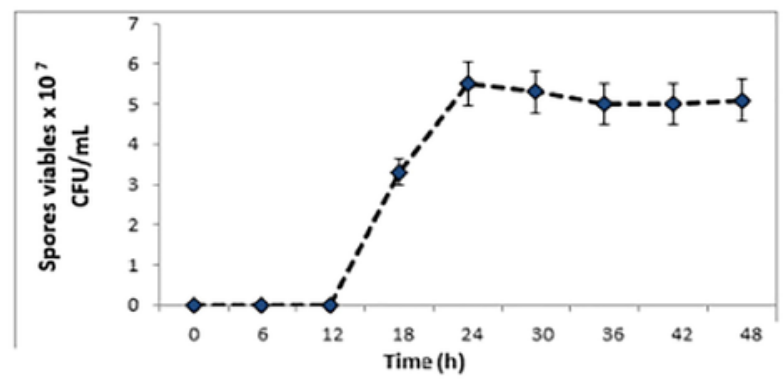

(c)

Fig. 1. . Fermentation profile for a) Endotoxin concentration b) Bt Cells (CFU/ mL) and c) Viable Spores (CFU/ mL) obtained during pilot plant study (2000 L capacity fermenter)

content and it can replace the expensive feedstocks used during fermentation process (Dang Vu et al., 2009; Gnepe et al., 2014).

Although studies have been reported for Bt based biopesticides using SIW (Dang Vu et al., 2009; Gnepe et al., 2014), an effective formulation of biopesticide, which ensures resistance to rainfall and UV rays has not been developed. Recently, a novel biopesticide production process has been developed in INRS laboratory where Bt cells, spores and endotoxins were produced during fermentation using SIW and formulation of biopesticide was performed using adjuvants to ensure its resistance against rainfall and UV rays (Ndao et al., 2017). The aim of this study was to investigate industrial feasibility of the novel biopesticide manufacturing process through techno-economic evaluation. Techno-economic studies of newly developed processes (formulated biopesticide production using SIW) is essential for their eventual application. The techno-economic evaluation reveals the actual economic impedances and bottlenecks which should be improved by the researcher for making the process (technology) economically feasible. An encouraging techno-economic evaluation has been performed using SuperPro designer software and Microsoft Excel and the results of same have been discussed in the study.

\section{Materials and methods}

\subsection{SIW composition}

Starch industry wastewater (SIW) had following composition: $\mathrm{pH}$ 3.5 , total solids (TS) concentration $15 \mathrm{~g} / \mathrm{L}$, volatile total solids (VS) concentration $11.2 \mathrm{~g} / \mathrm{L}$, suspended solids (SS) concentration $6.2 \mathrm{~g} / \mathrm{L}$, volatile suspended solids (VSS) concentration $3.2 \mathrm{~g} / \mathrm{L}$, total carbon content $375 \mathrm{~g} / \mathrm{kg}$ TS, total nitrogen content $30 \mathrm{~g} / \mathrm{kg}$ TS and ammoniacal nitrogen content $0.65 \mathrm{~g} / \mathrm{kg}$ TS. The SIW substrate mainly contains starch as a carbon source. The sugars present in SIW are glucose $(940 \mathrm{mg} / \mathrm{L})$, fructose $(290 \mathrm{mg} / \mathrm{L})$ and xylose $(790 \mathrm{mg} / \mathrm{L})$.

\subsection{Process description}

The complete process can be divided in to four-unit operations: (1) inoculum development (2) production fermenter, (3) centrifugation or product recovery and (4) formulation.

\subsubsection{Inoculum development}

Inoculum development was done in a series of reactors operated at $30{ }^{\circ} \mathrm{C}$ for $8 \mathrm{~h}$. Inoculum with $2 \% \mathrm{v} / \mathrm{v}$ of preculture of Bacillus thuringiensis subsp. Kurstaki cells was used for the next seed fermenter. SIW was used as carbon and nutrient source for the production of Bt cells. SIW was transported by the plant's truck to the site. SIW was sterilized at $121^{\circ} \mathrm{C}$ before inoculum transfer. The seed fermentation was conducted in aerobic conditions. Dissolved oxygen (DO) of the reactor was maintained above $30 \%$ during cell growth phase of seed fermentation. The reactor $\mathrm{pH}$ was maintained at 7.0.

\subsubsection{Production fermenter}

The fermentation was conducted in aerobic conditions. DO (dissolved oxygen) of the reactor was maintained near $60-70 \%$ during spore maturation for high entomotoxicity (Avignone-Rossa et al., 1992). The reactor $\mathrm{pH}$ was maintained at 7.0. SIW was sterilized at $121^{\circ} \mathrm{C}$ before inoculum transfer. During pilot runs, fermentation was operated in 1300 $\mathrm{L}$ working volume $\left(2000 \mathrm{~L}\right.$ reactor capacity) for $48 \mathrm{~h}$ at $30^{\circ} \mathrm{C}$ for production of Bt cells, spores and endotoxins (Ndao et al., 2017). For the pilot runs, fermentation was started with SIW and after a 48-hour fermentation period, the biomass (or suspended solids) concentration observed was $6 \mathrm{~g} / \mathrm{L}$. Endotoxins were released from the cells into the fermented broth at the end of fermentation (Ndao et al., 2017). Endotoxins released at the end of the pilot fermentation were $450 \mu \mathrm{g} / \mathrm{mL}$ of fermented broth. Entomotoxicity of 15 Billion International Units (BIU)/ $\mathrm{L}$ was observed in the fermented broth. The profile of spores, colony forming units and endotoxin concentration during pilot-plant runs is described in Fig. 1. 


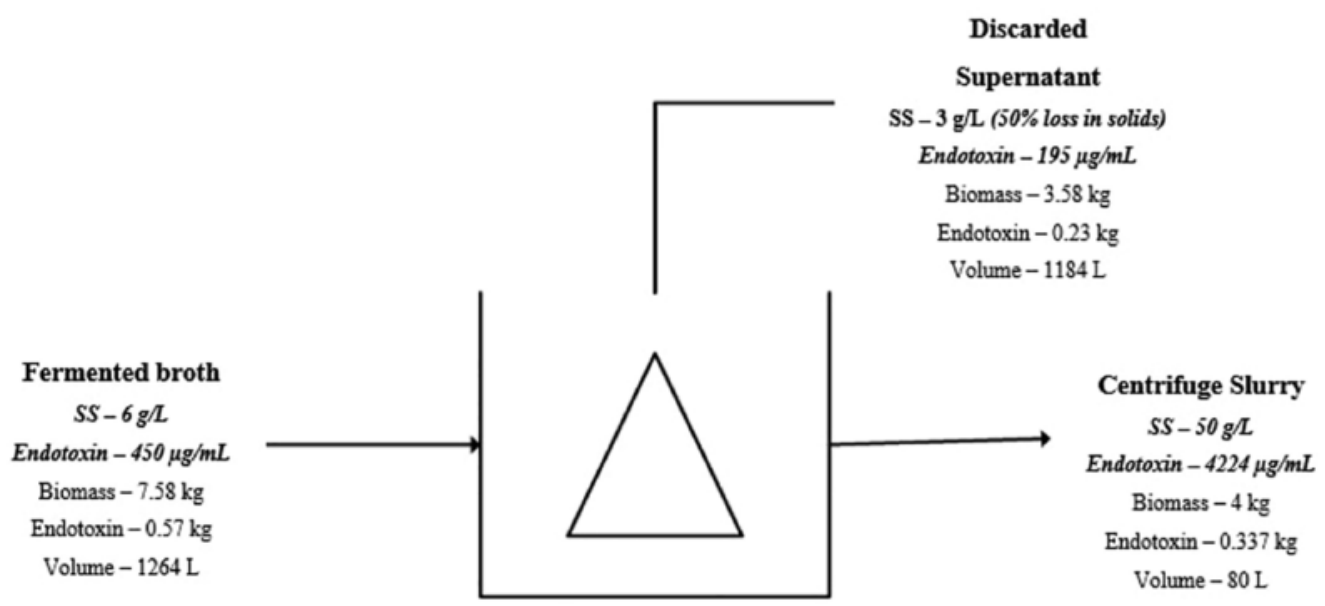

a)

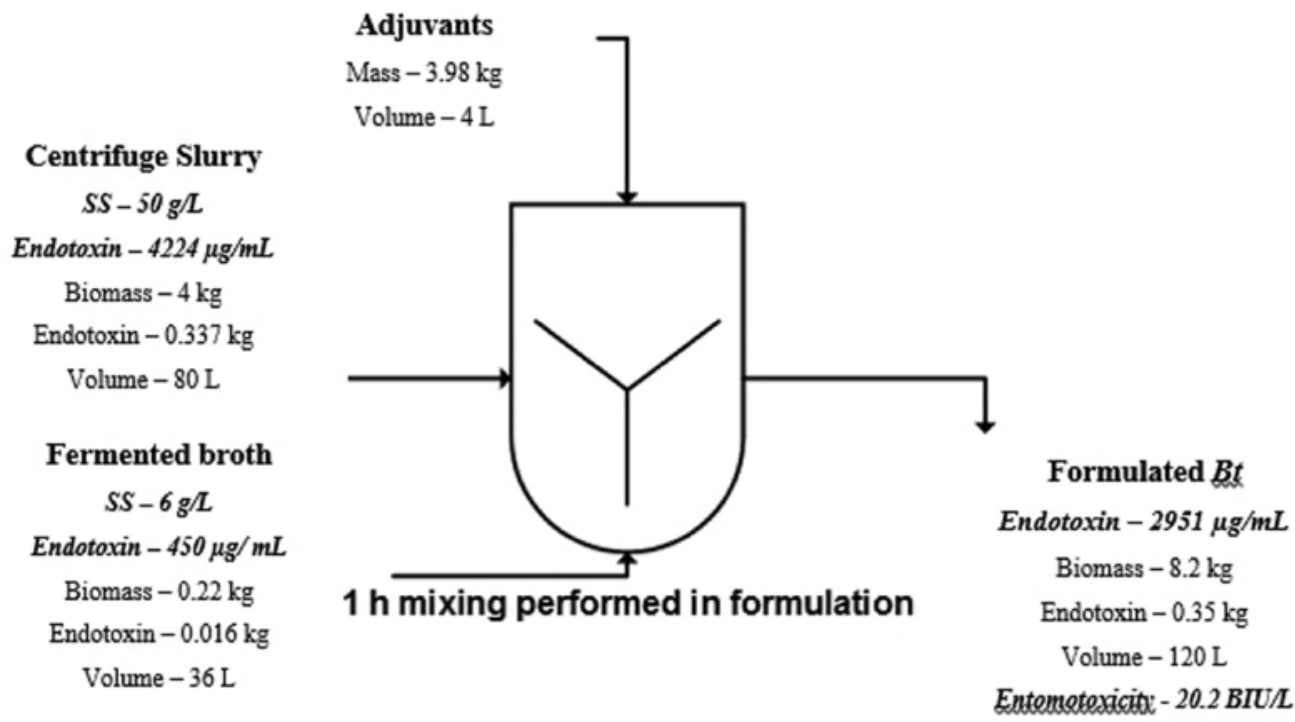

b)

Fig. 2. . Mass balance performed for a) centrifuge unit operation and b) formulation unit operation (pilot plant study data).

Table 1

Concentration of each component in the formulated biopesticide.

\begin{tabular}{lll}
\hline Adjuvant & $\%$ & Contribution in $120 \mathrm{~L}$ formulation \\
\hline Propionic acid & $0.06(\mathrm{v} / \mathrm{v})$ & $71 \mathrm{~mL}$ \\
Sorbic acid & $0.01(\mathrm{w} / \mathrm{v})$ & $10 \mathrm{~g}$ \\
Carboxy-methyl cellulose & $0.13(\mathrm{w} / \mathrm{v})$ & $150 \mathrm{~g}$ \\
Sorbitol & $0.83(\mathrm{w} / \mathrm{v})$ & $1000 \mathrm{~g}$ \\
Xanthan Gum & $0.17(\mathrm{w} / \mathrm{v})$ & $200 \mathrm{~g}$ \\
Molasses & $0.25(\mathrm{w} / \mathrm{v})$ & $300 \mathrm{~g}$ \\
Potassium silicate & $0.21(\mathrm{w} / \mathrm{v})$ & $250 \mathrm{~g}$ \\
Sodium acetate & $1.42(\mathrm{w} / \mathrm{v})$ & $1700 \mathrm{~g}$ \\
Acetic acid & $0.21(\mathrm{v} / \mathrm{v})$ & $238 \mathrm{~mL}$ \\
& &
\end{tabular}

\subsubsection{Broth harvesting by centrifugation}

During pilot plant runs, centrifugation was performed on $1264 \mathrm{~L}$ of fermented broth obtained from the pilot fermentation at $15,000 \mathrm{~g}$ (11800 rpm) to obtain $80 \mathrm{~L}$ concentrate of Bt cells, endotoxins and spores in a centrifuged slurry (15 times concentrate of fermented broth) while the lighter particles were discarded as supernatant. Solids concentration in supernatant $(3 \mathrm{~g} / \mathrm{L})$, suspended solids concentration in slurry (50 g/L), removal efficiency of centrifuge for endotoxins, cells, spores in slurry were obtained from the results of pilot plant data (Fig. 2a). The centrifuge was able to recover $57.76 \%$ endotoxin and $50.75 \%$ biomass in the centrifuged slurry.

\subsubsection{Formulation of biopesticide using adjuvants}

Concentrated slurry obtained after centrifugation $(80 \mathrm{~L})$ and fermented broth (36 L) were mixed for final formulation of the pilot fermentation. This ratio of mixing fermented broth and centrifuged slurry was optimized to obtain high entomotoxicity $(20.2 \mathrm{BIU} / \mathrm{L})$ in the final formulated biopesticide product. Along with centrifuged slurry and a part of fermented broth, adjuvants like sodium acetate with potassium silicate (act as buffering agent), molasses (for adhesion, UV protectant, phagostimulant), xanthan gum (for adhesion to foliage), sorbitol (act as flavoring agent), carboxy-methyl cellulose (act as emulsifier and 


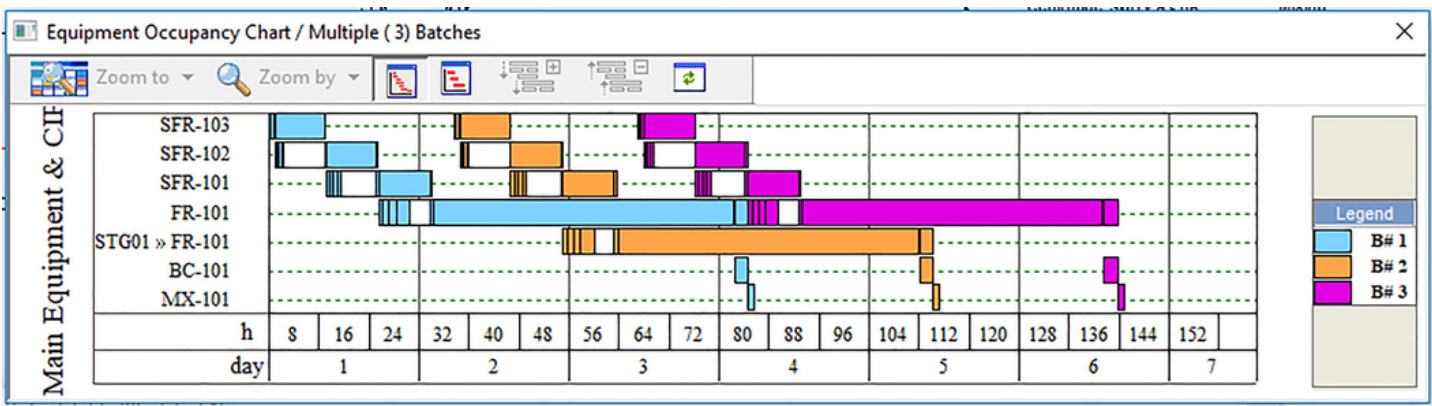

Fig. 3. . Gantt chart for processing of 3 consecutive batches.

Table 2

Process Timeline with description for one batch.

\begin{tabular}{|c|c|}
\hline Operation & Description \\
\hline \multicolumn{2}{|l|}{ Seed Fermentations } \\
\hline $\begin{array}{l}\text { Cleaning in Place } \\
\text { (CIP) }\end{array}$ & $\begin{array}{l}\text { Cleaning of equipment with water ( } 30 \% \text { of equipment } \\
\text { capacity) supplied at } 60^{\circ} \mathrm{C}\end{array}$ \\
\hline CHARGE-SIW & Charge starch industry wastewater to the seed fermenter \\
\hline $\begin{array}{l}\text { Sterilization at } \\
\quad 121^{\circ} \mathrm{C}\end{array}$ & $120 \mathrm{~min}$ (holding time of $15 \mathrm{~min}$ ) \\
\hline TRANSFER-Inoculum & Inoculum transfer through lobe pump \\
\hline COOL & Cooling to $30.0^{\circ} \mathrm{C}$ (cooling takes time around $120 \mathrm{~min}$ ) \\
\hline $\begin{array}{l}\text { Inoculum } \\
\text { development }\end{array}$ & Inoculum development for $8 \mathrm{~h}$ at $30.00^{\circ} \mathrm{C}$ \\
\hline FR-101 & Production Fermenter \\
\hline CIP & $\begin{array}{l}60 \text { min, Cleaning of equipment with water (with } 30 \% \text { of } \\
\text { equipment capacity) supplied at } 60^{\circ} \mathrm{C}\end{array}$ \\
\hline CHARGE- SIW & $\begin{array}{l}60 \mathrm{~min} \text {, Charge starch production industry wastewater to } \\
\text { production fermenter }\end{array}$ \\
\hline $\begin{array}{l}\text { Sterilization at } \\
121^{\circ} \mathrm{C}\end{array}$ & $180 \mathrm{~min}$ (including holding time of $15 \mathrm{~min}$ ) \\
\hline COOL & Cool to $30.0^{\circ} \mathrm{C}$ (cooling takes time around $180 \mathrm{~min}$ ) \\
\hline TRANSFER-Inoculum & $\begin{array}{l}60 \text { min - Transfer inoculum from seed fermenter to } \\
\text { production fermenter through lobe pump }\end{array}$ \\
\hline Fermentation & Fermentation for $48.00 \mathrm{~h}$, at $30.00^{\circ} \mathrm{C}$. \\
\hline $\begin{array}{l}\text { TRANSFER-OUT- } \\
\text { formulation }\end{array}$ & $\begin{array}{l}30 \text { min, Transfer } 2.77 \% \text { volume of fermented broth to } \\
\text { formulation unit through lobe pump }\end{array}$ \\
\hline TRANSFER-OUT & $\begin{array}{l}\text { Transfer } 97.23 \% \text { volume of fermented broth for } \\
\text { centrifugation }\end{array}$ \\
\hline BC-101 & Centrifugation \\
\hline CENTRIFUGATION & $\begin{array}{l}\text { Centrifuge } 1264 \mathrm{~L} \text { of broth for } 120 \mathrm{~min} \text { to concentrate cells, } \\
\text { spores and endotoxin in slurry }\end{array}$ \\
\hline MX-101 & Mixing/Formulation \\
\hline MIXING & Mixing of cells, spores, endotoxins and adjuvants for $1 \mathrm{~h}$ \\
\hline
\end{tabular}

stabilizer), sorbic acid, acetic acid and propionic acid (act as antimicrobial compounds) were added (Ndao et al., 2017). The composition of different adjuvants added in the formulation is shown in Table 1 (Ndao et al., 2017). Adjuvants were added to the mixture of centrifuged slurry and fermentation broth (obtained as above) and mixed in a tank for $1 \mathrm{~h}$, which resulted in final formulated Bt product. Mass balance was performed for formulation stepusing results of pilot-scale study data (Fig. $2 b)$.

\subsection{Simulation description and assumptions}

In this study, a process was simulated to produce formulated Bt product using starch industrial wastewater as substrate using SuperPro designer. The simulations were performed for the production of $500,000 \mathrm{~L}$ of formulated Bt product (20.2 Billion International Units $(\mathrm{BIU}) / \mathrm{L})$ in one year to meet the biopesticide demand in the province of Quebec, Canada. The plant was assumed to operate continuously for 350 days per year. The formulated stream of biopesticide produced by the plant is considered as the final product for simulation. Formulation was performed by using adjuvants, which ensure resistance to
Table 3

Mass balance performed for one batch $(500,000 \mathrm{~L}$ annual capacity)

\begin{tabular}{|c|c|c|c|c|c|}
\hline Stream & $\begin{array}{l}\text { Volume } \\
\text { (L) }\end{array}$ & $\begin{array}{l}\text { Endotoxin } \\
\text { conc. ( } \mu \mathrm{g} / \\
\mathrm{mL})\end{array}$ & $\begin{array}{l}\text { Endotoxin } \\
(\mathrm{g})\end{array}$ & $\begin{array}{l}\text { Total } \\
\text { biomass } \\
(\mathrm{kg})\end{array}$ & $\begin{array}{l}\text { Endotoxin } \\
\text { content \% } \\
(\mathrm{w} / \mathrm{w})\end{array}$ \\
\hline $\begin{array}{l}\text { Inoculum } \\
\text { (Fermenter } \\
\text { input 1) }\end{array}$ & 384 & - & - & 2.3 & - \\
\hline $\begin{array}{l}\text { SIW (Fermenter } \\
\text { input 2) }\end{array}$ & 18,823 & - & - & 75.3 & - \\
\hline $\begin{array}{l}\text { Fermented broth } \\
\text { for } \\
\text { centrifugation } \\
\text { (Centrifuge } \\
\text { Input) }\end{array}$ & 18,676 & 450 & 569 & 112 & 7.5 \\
\hline $\begin{array}{l}\text { Supernatant } \\
\text { from } \\
\text { centrifuge }\end{array}$ & 17,346 & 195 & 229 & 53 & 6.39 \\
\hline $\begin{array}{l}\text { Fermented broth } \\
\text { for } \\
\text { formulation } \\
\text { (Formulation } \\
\text { input 1) }\end{array}$ & 532 & 450 & 16 & 3.2 & 7.5 \\
\hline $\begin{array}{l}\text { Centrifuged } \\
\text { slurry } \\
\text { (Formulation } \\
\text { input 2) }\end{array}$ & 1182 & 4224 & 338 & 59.1 & 8.45 \\
\hline $\begin{array}{l}\text { Adjuvants } \\
\text { (Formulation } \\
\text { input 3) }\end{array}$ & 59 & 0 & 0 & 58.8 & 0 \\
\hline $\begin{array}{l}\text { Formulated } \\
\text { Biopesticide }\end{array}$ & 1773 & 2951 & 354 & 121.1 & 4.32 \\
\hline
\end{tabular}

precipitations (rain falls), UV rays and ensures good (homogenous) distribution of the suspension (Ndao et al., 2017). Formulated biopesticide is a mixture of endotoxins, cells, spores and adjuvants which are responsible for the toxic effect against the insects and pests. A plant continuously operating 350 days per year would result in 282 batches per annum while time between inoculation of two batches was $29.54 \mathrm{~h}$ and time to process each batch was $77.67 \mathrm{~h}$ (including $8 \mathrm{~h}$ each for 3 seed development stages, $48 \mathrm{~h}$ for production fermenter, $2 \mathrm{~h}$ for centrifuge and $1 \mathrm{~h}$ for formulation) (Fig. 3). Two production fermenters of $25,000 \mathrm{~L} \mathrm{ca-}$ pacity would be used for processing back-to-back batches. The complete description of process with individual step for each unit operation is described in Table 2.

\subsection{Economic evaluation}

The annual operational cost was calculated using all the significant components of production like raw material cost, labour cost, laboratory quality control (QC), waste disposal cost and utilities cost into account. Revenues production rates were obtained by the rigorous mass balance across the process and were multiplied with a unit price of the commodities available in the market to get annual revenues and credits. 
Table 4a

Distribution of equipment purchase cost (Freight on Board)

\begin{tabular}{|c|c|c|c|c|c|}
\hline Equipment & Capacity of actual equipment & Price of actual equipment (\$) & Number of units & Final cost (\$) & Cost $\%$ \\
\hline \multicolumn{6}{|l|}{ Process Equipment } \\
\hline Erlenmeyer Flask (SFR-103) & $500 \mathrm{~mL}$ & 50 & 1 & 50 & 0.00 \\
\hline Seed Fermenter (SFR-102) & $10 \mathrm{~L}$ & 25,000 & 1 & 25,000 & 0.61 \\
\hline Seed Fermenter (SFR-101) & $500 \mathrm{~L}$ & 150,000 & 1 & 150,000 & 3.65 \\
\hline Main fermenter (FR-101) & $25,000 \mathrm{~L}$ & 800,000 & 2 & $1,600,000$ & 38.98 \\
\hline Harvest \& feed vessel (HR-101 \& FV-101) & $25,000 \mathrm{~L}$ & 300,000 & 2 & 600,000 & 14.62 \\
\hline Centrifuge (BC-101) & $10 \mathrm{~m}^{3} / \mathrm{h}$ & 300,000 & 2 & 600,000 & 14.62 \\
\hline Lobe Pumps for transfer & 300 LPM & 50,000 & 4 & 200,000 & 4.87 \\
\hline Mixing unit (MX-101) & $2000 \mathrm{~L} / \mathrm{h}$ & 70,000 & 2 & 140,000 & 3.41 \\
\hline Software \& DCS & & 135,000 & 1 & 135,000 & 3.29 \\
\hline \multicolumn{6}{|l|}{ CIP system } \\
\hline CIP tank including pump \& DCS & & 160,000 & 1 & 160,000 & 3.90 \\
\hline CIP skid for transfer & & 1400 & 1 & 14,000 & 0.34 \\
\hline Heating element & & 1800 & 2 & 3600 & 0.09 \\
\hline \multicolumn{6}{|l|}{ Wastewater treatment plant } \\
\hline Neutralization tank & $10,000 \mathrm{~L}$ & 95,000 & 1 & 95,000 & 2.31 \\
\hline Reservoir/ kill tank & $7100 \mathrm{~L}$ & 172,000 & 1 & 172,000 & 4.19 \\
\hline Pump for $\mathrm{pH}$ neutralization & & 5000 & 1 & 5000 & 0.12 \\
\hline Pump for transfer to kill tank & & 18,000 & 1 & 18,000 & 0.44 \\
\hline SIW transportation truck & $20,000 \mathrm{~L}$ & 110,000 & 1 & 110,000 & 2.66 \\
\hline Water purification unit & & 100,000 & 1 & 100,000 & 2.42 \\
\hline Total equipment cost (Million \$) & & & & 4.13 & 100.00 \\
\hline
\end{tabular}

Table 4b

Direct fixed cost of the plant (500,000 L capacity)

\begin{tabular}{lll}
\hline \multicolumn{2}{l}{ a.Total plant direct cost (TPDC) } & Million \$ \\
\hline Equipment Purchase Cost, PC & & 4.13 \\
\hline Equipment Installation & $30 \%$ of PC & 1.24 \\
\hline Process Piping & $30 \%$ of PC & 1.24 \\
Instrumentation & $25 \%$ of PC & 1.03 \\
Insulation & $8 \%$ of PC & 0.33 \\
Electrical & $10 \%$ of PC & 0.41 \\
Building & $20 \%$ of PC & 0.83 \\
Yard Improvement & $10 \%$ of PC & 0.41 \\
Auxiliary Facilities & $25 \%$ of PC & 1.03 \\
TPDC & & 10.65 \\
b. Total Plant Indirect Cost (TPIC) & & \\
Engineering & $8 \%$ of TPDC & 0.85 \\
Construction & $10 \%$ of TPDC & 1.06 \\
TPIC & & 1.92 \\
Total Plant COST (TPC $=$ TPDC + TPIC) & 12.57 \\
c. CONTRACTOR FEE \& CONTINGENCY (CFC) & \\
Contractor's Fee & $5 \%$ of TPC & 0.63 \\
Contingency Fee & $15 \%$ of TPC & 1.88 \\
CFC & & 2.51 \\
Direct Fixed Cost (DFC $=$ CFC + TPC) & $\mathbf{1 5 . 0 8}$ \\
\hline
\end{tabular}

Table 5

Distribution of annual operating cost (500,000 L capacity)

\begin{tabular}{llll}
\hline Item & Description & Annual cost (\$) & \% of AOC \\
\hline Operating Labour & & 750,000 & 29.05 \\
Supervisory labour & 15\% of operating labour & 112,500 & 4.36 \\
Quality Lab Control & 15\% of operating labour & 112,500 & 4.36 \\
Raw material cost & & 240,909 & 9.33 \\
Utilities & 158,832 & 6.15 \\
Facility dependent & & $1,206,357$ & 46.72 \\
Waste treatment & 820 & 0.03 \\
Annual Operating cost, AOC (Million \$) & $\mathbf{2 . 5 8}$ & $\mathbf{1 0 0}$
\end{tabular}

\subsection{Revenue and profitability analysis}

To evaluate the profitability of the process, gross margin, return on investment (ROI), gross profit and payback time was calculated
Table 6

Profitability analysis for the production of biopesticide using starch industry wastewater for different capacities

\begin{tabular}{|c|c|c|c|c|c|}
\hline \multicolumn{6}{|l|}{ Investment details } \\
\hline Plant Capacity & 500,000 & $\begin{array}{l}1 \\
\text { million }\end{array}$ & $\begin{array}{l}5 \\
\text { million }\end{array}$ & $\begin{array}{l}10 \\
\text { million }\end{array}$ & $\mathrm{L} /$ year \\
\hline \multicolumn{6}{|c|}{ Total investment to start the project } \\
\hline $\begin{array}{l}\text { Production Fermenter } \\
\text { capacity (L) }\end{array}$ & 25,000 & 50,000 & 250,000 & 500,000 & $\mathrm{~L}$ \\
\hline Direct Fixed Capital & 15.08 & 22.86 & 60.03 & 90.99 & $\begin{array}{l}\text { million } \\
\$\end{array}$ \\
\hline $\begin{array}{l}\text { Working Capital ( } 20 \% \\
\text { of DFC) }\end{array}$ & 3.02 & 4.57 & 12.01 & 18.2 & $\begin{array}{l}\text { million } \\
\$\end{array}$ \\
\hline Total Investment & 18.1 & 27.43 & 72.04 & 109.19 & $\begin{array}{l}\text { million } \\
\$\end{array}$ \\
\hline \multicolumn{6}{|c|}{ Revenue Production rates } \\
\hline $\begin{array}{l}\text { Formulated BT annual } \\
\text { production }\end{array}$ & 0.5 & 1 & 5 & 10 & $\begin{array}{l}\text { million } \\
\text { L per } \\
\text { year }\end{array}$ \\
\hline $\begin{array}{l}\text { Formulated BT } \\
\text { selling price }\end{array}$ & 10 & 10 & 10 & 10 & $\$ / L$ \\
\hline Revenue Generated & & & & & \\
\hline $\begin{array}{l}\text { Formulated BT } \\
\text { product sale }\end{array}$ & 5 & 10 & 50 & 100 & $\begin{array}{l}\text { million } \\
\$ / \text { year }\end{array}$ \\
\hline \multicolumn{6}{|l|}{ Annual Operating cost } \\
\hline $\begin{array}{l}\text { Annual Operating } \\
\text { Cost }\end{array}$ & 2.58 & 3.8 & 12.72 & 18.31 & $\begin{array}{l}\text { million } \\
\$ / \text { year }\end{array}$ \\
\hline Unit Production Cost & 5.16 & 3.8 & 2.54 & 1.83 & $\$$ per $L$ \\
\hline $\begin{array}{l}\text { Unit production } \\
\text { revenue }\end{array}$ & 10 & 10 & 10 & 10 & $\$$ per $L$ \\
\hline Unit profit & 4.84 & 6.2 & 7.46 & 8.17 & \$ per L \\
\hline $\begin{array}{l}\text { Profit earned by } \\
\text { company }\end{array}$ & 2.42 & 6.2 & 37.28 & 81.69 & $\begin{array}{l}\text { million } \\
\$ / \text { year }\end{array}$ \\
\hline $\begin{array}{l}\text { Depreciation ( } 1 \% \\
\text { DFC) }\end{array}$ & 0.15 & 0.23 & 0.6 & 0.91 & $\begin{array}{l}\text { million } \\
\$ / \text { year }\end{array}$ \\
\hline $\begin{array}{l}\text { Gross profit earned by } \\
\text { company }\end{array}$ & 2.27 & 5.97 & 36.68 & 80.78 & $\begin{array}{l}\text { million } \\
\$ / \text { year }\end{array}$ \\
\hline $\begin{array}{l}\text { Taxes paid by } \\
\text { company }(30 \%)\end{array}$ & 0.68 & 1.79 & 11 & 24.23 & $\begin{array}{l}\text { million } \\
\$ / \text { year }\end{array}$ \\
\hline $\begin{array}{l}\text { Net Profit earned by } \\
\text { company }\end{array}$ & 1.89 & 4.64 & 26.87 & 58.36 & $\begin{array}{l}\text { million } \\
\$ / \text { year }\end{array}$ \\
\hline Gross Margin & 48.36 & 61.97 & 74.56 & 81.69 & $\%$ \\
\hline ROI & 10.44 & 16.9 & 37.31 & 53.45 & $\%$ \\
\hline Payback time & 9.58 & 5.92 & 2.68 & 1.87 & Years \\
\hline
\end{tabular}




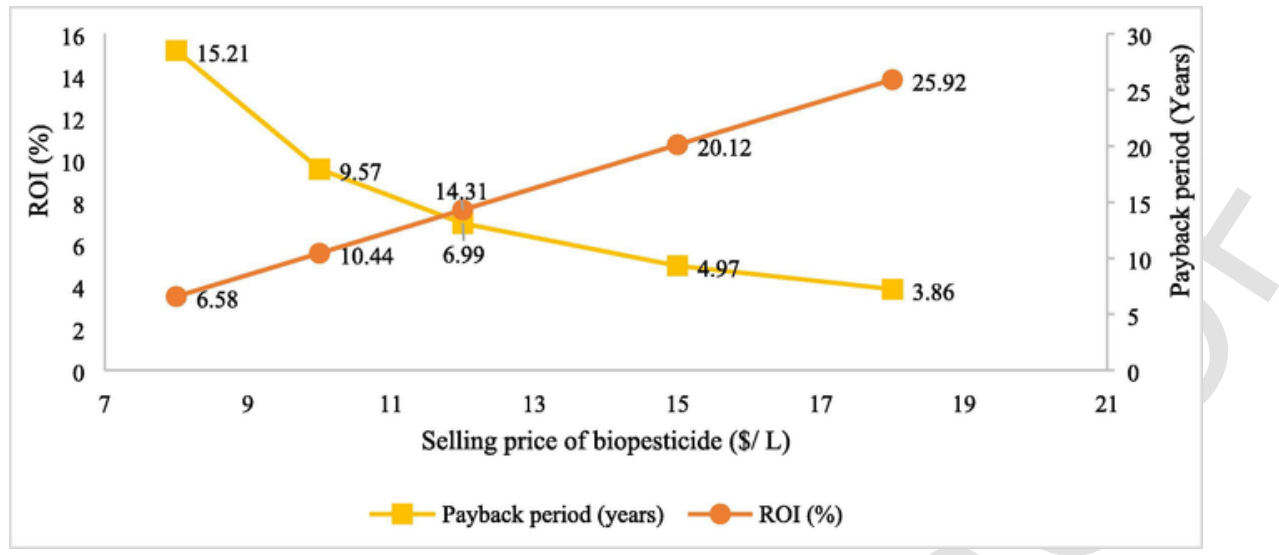

Fig. 4. . Profitability sensitivity to selling price of biopesticide.

according to following scheme (Eqs. 1-4).

$$
\begin{aligned}
\text { GrossProfit }= & \text { Revenue }(s)-\text { Annualoperatingcost } \\
& - \text { Depreciation }
\end{aligned}
$$

\section{Grossmargin(\%) \\ $=\frac{\text { Revenue }- \text { Annualoperatingcost }}{\text { revenue }} * 100$}

Netprof it $=$ Grossprof it - Taxespaidbythecompany

$\boldsymbol{R O I}(\%)=\frac{\text { Netprofit }}{\text { TotalInvestment }} * 100$

Paybacktime $($ years $)=\frac{\text { TotalInvestmet }}{\text { Netprofit }}$

\section{Results and discussion}

\subsection{Economic evaluation}

\subsubsection{Mass balance}

Endotoxin and cell recovery during centrifugation were used from the results of the $2000 \mathrm{~L}$ pilot plant study data. The concentration of suspended solids in SIW ( $4 \mathrm{~g} / \mathrm{L})$, fermented broth $(6 \mathrm{~g} / \mathrm{L})$, centrifuged slurry $(50 \mathrm{~g} / \mathrm{L})$ and adjuvants stream $(995 \mathrm{~g} / \mathrm{L})$ was taken from the pilot plant data for simulation. Mass balance of the complete process for one batch at designed scale is summarized in Table 3. Although endotoxin content in formulated biopesticide was $4.32 \%(\mathrm{w} / \mathrm{w})$ but active ingredients including Bt cells, spores and endotoxins account for approximately $51 \%$ $(\mathrm{w} / \mathrm{w})$ of the final formulated stream while remaining $49 \%(\mathrm{w} / \mathrm{w})$ are adjuvants.

\subsubsection{Equipment sizing}

Stainless steel grade 304 (SS304) was chosen as material of construction for the equipment. SS304, with its chromium-nickel content and low carbon, is the most versatile and widely used type of stainless steel. It contains $18 \%$ chromium and $8 \%$ nickel. SS304 is resistant to oxidation, corrosion, and durable for this type of application (Phadnis et al., 2003). All seed and production fermenters were built with design pressure of 1.5 bars and H/D ratio (Height to diameter) of 3. Two fermenters of capacity 25,000 L each were considered for calculations for operating consecutive batches. Two tanks of 25,000 L (similar capacity as that of production fermenter) were also accounted - one tank for feeding SIW into the production fermenter and one tank used as a harvest vessel.

Fermented broth of $18,676 \mathrm{~L}$ needs to be centrifuged in $2 \mathrm{~h}$. Centrifugation time was considered based on pilot plant operational effectiveness. Reducing the centrifugation operation time requires centrifuge with high throughput capacity, which further increases the purchase cost of centrifuge (equipment cost). Moreover, in the process, fermentation time is the pacing factor for determining the number of batches in a year. Hence, throughput of centrifuge required was calculated to be $9.34 \mathrm{~m}^{3} / \mathrm{h}(18676 \mathrm{~L}$ in $2 \mathrm{~h})$. Two centrifuges with a $10 \mathrm{~m}^{3} / \mathrm{h}$ capacity each are required for the operation. The additional centrifuge also allows for redundancy. Formulated Bt product of $1773 \mathrm{~L}$ is to be formulated in $1 \mathrm{~h}$ for each batch. Two mixing units with maximum capacity of $2000 \mathrm{~L} / \mathrm{h}$ each are therefore assumed for calculations.

\subsubsection{Equipment purchase cost}

The equipment purchase cost was estimated in US\$. The assumed prices for the equipment were derived from studies and quotations provided by different manufacturers. Table $4 \mathrm{a}$ summarizes equipment costs. The total equipment purchase cost has been divided into various sub-sections - process equipment, cleaning-in-place (CIP) generation system, wastewater treatment plant, water purification system and distributed control system (DCS). Total equipment purchase costs were estimated to be 4.13 million \$. Process equipment contributes to $80.72 \%$ of total equipment purchase costs, CIP generation system (with a tank, skid, transfer pump, heating element and a programmable logic controller PLC) contributes to $4.32 \%$ and wastewater treatment plant (including a kill tank, neutralization tank and transfer pumps) to 7.03\%. The plant would be operated through complete automation with a DCS (distributed control system with software, analog input/output and personal computer) which costs around 0.13 million dollars contributing $3.29 \%$ of total equipment purchase costs. The price of a truck for carrying 20,000 L of SIW to the plant is estimated at 0.11 million dollars and contributes to $2.66 \%$ of total equipment purchase costs. For the plant operations, purified water is used for CIP and for same, water purification unit has been considered. Water purification unit (using reverse osmosis) contributes to $2.42 \%$ of total equipment purchase costs.

In the process equipment, two fermentation reactors accounted for the largest contributor to the equipment costs (38.98\%). The two centrifuges required for concentrating the cells, spores and endotoxins account for $14.62 \%$ of total equipment costs. Two tanks (feed tank and harvest tank) account for $14.62 \%$ of total equipment purchase costs. Lobe pumps (500 LPM) for inoculum transfer, SIW transfer to production fermenter, transfer of fermented broth to the formulation unit have also been accounted for in the process equipment costs. 


\subsubsection{Direct fixed cost (DFC)}

Direct fixed cost of the plant comprises different plant cost elements: a. Plant direct cost which includes equipment purchase cost, cost of installation, piping, instrumentation, building, facilities etc. b. Plant indirect cost which includes plant construction and engineering cost and c. Contractor fee and contingency fees.

The total plant direct cost (TPDC) includes cost elements which are incurred for the establishment of the facility. The TPDC comprises of equipment purchase cost, equipment installation cost, their instrumentation, insulation, electrical connection, cost for building development, improvement of the yard and other auxiliary charges. In this process plant, typical scheme of calculations was used, which often are used as rule of thumb for such bioprocesses. The scheme of calculation of plant direct cost was taken from Chen et al. (2018).

The installation cost of the equipment includes setting-up of platforms and supports for the equipment and its erection. Including material and labor cost for the installation, the equipment installation cost was considered to be $30 \%$ of the equipment purchase cost. The piping cost includes valves, fittings, pipe, supports required for the laying of all piping to be used in the process. Piping cost was considered to be $30 \%$ of equipment purchase cost. The instrumentation cost is the major cost in the capital investment of the plant. Twenty-five $\%$ of equipment purchase cost has been considered for fully automated plant operations with use of pneumatic instrumentation. For insulation over equipment and piping: the insulation cost has been considered to be $8 \%$ of total equipment purchase cost. Electrical installation consists of power wiring, lighting, instrument wiring, etc. and it was estimated to be equivalent to $10 \%$ of equipment purchase cost. The yard improvement costs consist of fencing, roads, sidewalks etc. and it is equivalent to $10 \%$ of equipment purchase cost. Constructing a new facility with heating and ventilation facilities cost around $20 \%$ of equipment purchase cost while service facilities like utilities for supply of steam, power, chilled water, etc. cost around $25 \%$ of total equipment cost. Accordingly, 10.65 million dollars was estimated as total plant direct cost (Table 4b).

There are various other indirect cost factors, like engineering and construction which should be accounted. The engineering cost required to properly engineer the plant for required production is separately accounted ( $8 \%$ of total plant direct cost). Further construction of the whole facility requires other additional charges, which can be accounted under the head of construction cost. Contingency fee is also incorporated to account for variation in the cost-estimate, which was considered to be $15 \%$ of additional sum of indirect and direct plant cost. Direct Fixed Cost $(\mathrm{DFC})=\mathrm{TPDC}+$ Construction cost + Engineering cost + Contractor fee + contingency. The DFC for the process was calculated to be 15.08 million dollars (Table 4b).

\subsection{Annual operating cost}

The annual operational cost was calculated using all the significant components of production which include: raw material cost, labour cost, quality control, waste treatment, facility dependent and utilities. The cost of treating aqueous waste was taken from Ram et al. (2018) and fed into the software for calculating annual waste treatment cost. The average salary of plant operators was considered from database of the software.

\subsubsection{Raw materials cost}

Different components of the raw material required for the process include starch industry wastewater (SIW), which is used as substrate for fermentation and adjuvants that are used during formulation. The cost of different raw materials was taken from bulk price from the internet and fed into the software for calculating annual requirement of raw material. Cost of industrial water consumption (used during cleaning of fermenters) was considered from 'Ministère des affaires municipales et des régions (Quebec)'. Starch producing industry wastewater (SIW), which was used as principal carbon source as well as source of other nutrients, has no cost or zero cost. However, the cost of SIW transportation within a range of $200 \mathrm{~km}$ has been assumed, which is 200 $\$$ /trip (based on fuel cost and $20000 \mathrm{~L}$ of SIW that can be brought into a single trip). The purchase of the truck for SIW transportation has been included in equipment purchase cost. Annual expenditure for raw material purchase was 240,910 \$. Considering all raw materials, the most cost intensifying factor was water $(66.25 \%)$ used for cleaning of seed and production fermenters after every batch followed by SIW transportation cost, which accounts for $23.41 \%$ of total raw materials cost. Adjuvants added during formulation account for $10.24 \%$ of total raw materials cost.

\subsubsection{Utilities cost}

For all the heating and cooling requirements of the process various utilities like steam, chilled water and standard power are used in the process plant. Standard electrical power and steam (12\$/MT) are most frequently used for heat generation, and mechanical transport of materials. For cooling purpose, chilled water $(0.4 \$ / \mathrm{MT})$ is used to maintain lower temperatures. Standard electricity $(0.1 \mathrm{\$} / \mathrm{kW}-\mathrm{h})$ to operate the centrifuge and production fermenters account for $65.3 \%$ of annual utility cost. The annual requirement of standard power $\left(3 \mathrm{~kW} / \mathrm{m}^{3}\right.$ fermentation broth during agitation and $30.76 \mathrm{~kW}$ during centrifugation and mixing), steam $(24.16 \mathrm{~kg} / \mathrm{h})$ and chilled water $(9807.8 \mathrm{~kg} / \mathrm{h})$ was calculated from the software based on the process requirement. A total sum of 158,832 dollars is needed annually to run the plant.

\subsubsection{Operating labour cost}

Based on labour cost of $19.5 \$ / \mathrm{h}$, annual labour operating cost calculated from the software was $750000 \$$. Fifteen operators at average pay-scale of $50000 \$ /$ year are required to operate the facility: 3 dedicated for seed fermenters, 5 dedicated for production fermenters, 2 dedicated for centrifuge and formulation, 3 for warehouse (out of three, one can be used for SIW transportation) and 2 for purchase and accounts department. Supervisory and quality control (QC) labour has been considered to be $15 \%$ each of annual operating labour.

\subsubsection{Facility-dependent cost (Maintenance and repair)}

Facility-dependent cost comprises of plant annual maintenance cost, insurances, local taxes and factory expenses. The maintenance and repair cost are for proper running of the facility. This cost is $3 \%$ of the direct fixed cost (DFC). Taxes are also imposed on the facility dependent cost. Insurance charges, local taxes and other factory expenses are estimated as $1 \%, 1 \%$ and $3 \%$ of the DFC (direct fixed cost), respectively. The total facility dependent cost for this facility was calculated to be 1,206,357 dollars.

\subsubsection{Waste disposal cost}

Annually $7452 \mathrm{~m}^{3}$ of aqueous waste is generated after CIP of fermenters and supernatant (obtained after centrifugation of fermented broth), which is disposed at the rate of $\$ 0.11 / \mathrm{m}^{3}$. Annually waste disposal cost is $820 \$$.

Annual operating cost analysis (Table 5) reveals that $46.72 \%$ of the total annual operating cost is because of facility dependent cost for maintenance and repair of the facility. Annual operating labour cost (including operating, supervisory labour and QC or quality control), account for $37.77 \%$ of annual operating cost (Table 5). A total sum of 2.58 million dollars is required to annually run the facility. 


\subsection{Profitability analysis}

The total capital investment for the project is calculated on the basis of direct fixed capital cost to set-up the plant, working capital required to conduct trial and validation batches before actual commercialization of the plant ( $20 \%$ of DFC). The total investment to start the project (for annual production of $500,000 \mathrm{~L}$ biopesticide) is 18.1 million $\$$ (Table $6)$. The profitability of the process is highly dependent on the relative prices to sell the final product, which decides the annual revenue of the process and eventually decides the gross profits and payback periods. During annual operation of the process, $500,000 \mathrm{~L}$ of formulated Bt product is produced as revenue stream. The selling price of formulated biopesticide was set to $10 \$ / \mathrm{L}$ (bulk price from the internet). Through annual operating cost and quantity of formulated Bt produced annually, the unit production cost calculated was $\$ 5.16 / \mathrm{L}$ (Table 6).

In the present study, the unit production cost of biopesticide using starch industry wastewater was \$ $0.255 / \mathrm{BIU}$, which was similar to reported by Brar et al. (2007). The unit production cost of Bt based biopesticide (obtained using SIW) by Brar et al. (2007) was $\$ 0.248$ / BIU. The difference in present study and the reported study lies in the plant capacity, downstream process efficiency and formulation. Brar and co-workers' study was conducted using batch centrifuge with $48,000 \mathrm{~g}$ centrifugal force, which resulted in $95 \%$ recovery of entomotoxicity while the present study was conducted using centrifugal force of $15,000 \mathrm{~g}$ in a continuous centrifuge, which simulates results very near to industrial practice. In the present study, centrifuge recovery of endotoxins obtained was $57.76 \%$. Further, Brar et al. (2007) prepared the formulation using only molasses while in the present study, a complete formulation was prepared using mixture of adjuvants including molasses to meet the requisite of an applicable formulation (UV resistant, rainfastness, stable suspension, antimicrobial growth etc.). The annual plant capacity in the reported study was $3 \times 10^{7} \mathrm{BIU} /$ year which is 3 times the plant capacity considered in the present study. Another study has been reported for $B$. thuringiensis $(\mathrm{Bt})$ based bioinsecticides which was produced using corn syrup and corn steep liquor as carbon and nitrogen source and unit cost was estimated to be \$0.45/BIU (Rowe and Margaritis, 2004). The price of biopesticide in this study is competitive to price of chemical pesticides which varies from $\$ 4 / \mathrm{L}-\$ 15 / \mathrm{L}$ (bulk price from internet).

Payback time is defined as the period in which the company can recover all its investment costs through the profits earned by selling the product. The payback of the complete investment (for annual capacity of $500,000 \mathrm{~L}$ ) can be achieved in 9.58 years (Table 6). Return on investment (ROI) is used to evaluate the efficiency of an investment. In purely economic terms, it is a way of relating profits to the capital invested. ROI for annual capacity of $500000 \mathrm{~L}$ is $10.44 \%$ (Table 6).

\subsection{Sensitivity analysis}

\subsubsection{Plant capacity}

All equipment costing for higher capacities was carried out by power law model using the Eq. (6).

$C=C_{o}\left(\frac{S}{S_{0}}\right)^{n}$

where, $C$ is the cost of equipment of dimension values $S$ whereas $C_{o}, S_{o}$ and $\mathrm{n}$ are cost of reference equipment, scale information about reference equipment and size exponent factor respectively, available in the literature (Chen et al., 2018; Ram et al., 2018; Sweeting, 1997).

Plant capacity affects the unit cost of production (Table 6). Hence, while setting up a new facility, the manufacturer should keep a perspective of annual scale of production besides the market demand as annual profits, ROI, payback period is dependent on the unit production cost which is further dependent on the scale of production. At higher plant capacities, the unit production cost decreases as \% of facility dependent cost (with respect to annual operating cost) decreases as high scale equipment proves more economical than small scale equipment (for eg. The purchase cost of one 10,000 L fermenter is $259575 \$$ while two $5000 \mathrm{~L}$ fermenters cost around 324036\$). Table 6 illustrates that on increasing the annual scale of operation from 0.5 million $\mathrm{L}$ to 10 million $\mathrm{L}$ decreases the unit production cost from 5.16 \$/ L to 1.83 \$/ L. Table 6 compares profitability analysis for different plant capacities. The manufacturer should target 5 million L formulated biopesticide as payback time is below 4 years and ROI is above $35 \%$ (Table 6).

\subsubsection{Selling price of formulated Bt product}

Since ROI and payback period are dependent on the selling price of the product. Hence, a simulation has been performed for varying the selling price of formulated Bt product for same design capacity (500000 L/year) to study the impact on profitability (Fig. 4). As the selling price of formulated Bt product is increased, annual profits increase due to which ROI increases and payback time decreases consecutively. As the selling price of formulated Bt product is incresed from $8 \$ / \mathrm{L}$ to $18 \$ / \mathrm{L}$, ROI (\%) linearly increases. ROI of $25.92 \%$ was estimated for selling price of $18 \$ / \mathrm{L}$ with payback time of 3.86 years. With for selling price of $8 \$ / \mathrm{L}$, the payback period of the investment was 15.21 years while return on investment was $6.58 \%$.

In the present study, endotoxin concentration obtained in fermented broth was $450 \mu \mathrm{g} / \mathrm{mL}$. In another study, Bacillus thuringiensis (Bt) biopesticide was produced using food waste with different water contents. The semi-solid state fermentation with $75 \%$ water content resulted in $\delta$-endotoxin concentration of $862 \mu \mathrm{g} / \mathrm{mL}$. $\delta$-endotoxin concentration further increased by $73.8 \%$ with submerged fermentation with $99 \%$ water content (Zhang et al., 2015). In the present study, centrifuge (continuous mode operation) was able to recover $57.76 \%$ of total endotoxins in the centrifuged slurry. The other studies have not reported the endotoxin recovery during centrifugation process. Centrifuge recovery can be enhanced by addition of centrifugal-aid flocculants like tannic acid and chitosan. Increasing the centrifuge efficiency can enhance the entomotoxicity of formulated Bt product, which can be sold at higher price and could increase the profitability.

\section{Conclusion}

In this study, Bacillus thuriengensis based biopesticide formulation was produced using SIW as substrate. The techno-economic evaluation of the production process revealed that the manufacturer should target 5 million L annual plant capacity and selling price of $\$ 15 / \mathrm{L}$ for payback period to be less than 5 years. The unit production cost was estimated to be $\$ 2.54 / \mathrm{L}$ for 5 million L plant capacity. In the process, centrifuge was able to recover $57.76 \%$ of total endotoxins in the centrifuged slurry. Increasing the centrifuge efficiency can further increase the economic viability of the process.

\section{Acknowledgements}

Authors would like to acknowledge the Natural Sciences and Engineering Research Council of Canada (grant A4984, Canada Research Chair) for financial support. The authors are grateful to PAGEAU MOREL and LAVAL LAB for providing quotations for the equipment. The authors are also grateful to Dr. Saurabh Kumar Ram (Bioprocess Consultant, Sanofi) and Dr. Drouin Mathieu (Operation chief, INRS pilot laboratory) for their valuable suggestions in writing the manuscript. 


\section{References}

Avignone-Rossa, C., Arcas, J., Mignone, C., 1992. Bacillus thuringiensis growth, sporulation and $\delta$-endotoxin production in oxygen limited and non-limited cultures. World $\mathrm{J}$. Microbiol. Biotechnol. 8 (3), 301-304.

Azmi, N.U., Ghafar, N.S.A., Yin, C.J., Yakubu, S., Adli, A.A., Aziz, N.A.A., Mustafa, M., 2015. Toxicity of Bacillus thuringiensis biopesticide produced in shrimp pond sludge as alternative culture medium against Bactrocera dorsalis (Hendel). Acta Biol. Malays. 4 (1), 5-16.

Ballardo, C., Abraham, J., Barrena, R., Artola, A., Gea, T., Sánchez, A., 2016. Valorization of soy waste through SSF for the production of compost enriched with Bacillus thuringiensis with biopesticide properties. J. Environ. Manage. 169, 126-131.

Ballardo, C., Barrena, R., Artola, A., Sánchez, A., 2017. A novel strategy for producing compost with enhanced biopesticide properties through solid-state fermentation of biowaste and inoculation with Bacillus thuringiensis. Waste Manage. 70, 53-58.

Brar, S., Verma, M., Tyagi, R., Valéro, J., Surampalli, R., 2005. Sludge based Bacillus thuringiensis biopesticides: viscosity impacts. Water Res. 39 (13), 3001-3011.

Brar, S.K., Verma, M., Tyagi, R., Valéro, J., 2006. Recent advances in downstream processing and formulations of Bacillus thuringiensis based biopesticides. Process Biochem. 41 (2), 323-342.

S.K. Brar, M. Verma, R. Tyagi, J. Valéro, R. Surampalli, 2007. Techno-economic analysis of Bacillus thuringiensis biopesticides production from wastewater and wastewater sludge. Moving Forward Wastewater Biosolids Sustainability: Technical, Managerial, and Public Synergy, 731-738.

Cannon, R.J., 1993. Prospects and progress for Bacillus thuringiensis-based pesticides. Pest Manag. Sci. 37 (4), 331-335.

Chen, J., Tyagi, R.D., Li, J., Zhang, X., Drogui, P., Sun, F., 2018. Economic assessment of biodiesel production from wastewater sludge. Bioresour. Technol. 253, 41-48.

Copping, L.G., 1998. The biopesticide manual: world compendium. British crop protection council.

Dang, Vu., Tyagi, K., Brar, R., Valéro, S., Surampalli, J., 2009. Starch industry wastewater for production of biopesticides-Ramifications of solids concentrations. Environ. Technol. 30 (4), 393-405.

Elleuch, J., Jaoua, S., Ginibre, C., Chandre, F., Tounsi, S., Zghal, R.Z., 2016. Toxin stability improvement and toxicity increase against dipteran and lepidopteran larvae of Bacillus thuringiensis crystal protein Cry2Aa. Pest Manag. Sci. 72 (12), 2240-2246.

Gnepe, J.R., Tyagi, R.D., Brar, S.K., Valéro, J.R., Surampalli, R.Y., 2014. Corrosion and stability study of Bacillus thuringiensis var. kurstaki starch industry wastewater-derived biopesticide formulation. J. Environ. Sci. Health, Part B 49 (11), 889-896.

Marrone, P.G., 1999. Microbial pesticides and natural products as alternatives. Outlook on AGRICULTURE 28 (3), 149-154.
Melo, A.L.d.A., Soccol, V.T., Soccol, C.R., 2016. Bacillus thuringiensis: mechanism of action, resistance, and new applications: a review. Crit. Rev. Biotechnol. 36 (2), 317-326.

Ndao, A., Sellamuthu, B., Gnepe, J.R., Tyagi, R.D., Valero, J.R., 2017. Pilot-scale biopesticide production by Bacillus thuringiensis subsp. kurstaki using starch industry wastewater as raw material. J. Environ. Science and Health, Part B 52 (9), 623-630.

Osman, G., Already, R., Assaeedi, A., Organji, S., El-Ghareeb, D., Abulreesh, H., Althubiani, A., 2015. Bioinsecticide Bacillus thuringiensis a comprehensive review. Egypt. J. Biol. Pest Control 25 (1), 271.

Phadnis, S., Satpati, A., Muthe, K., Vyas, J., Sundaresan, R., 2003. Comparison of rolled and heat treated SS304 in chloride solution using electrochemical and XPS techniques. Corros. Sci. 45 (11), 2467-2483.

Ram, S.K., Kumar, L., Tyagi, R.D., Drogui, P., 2018. Techno-economic evaluation of simultaneous production of extra-cellular polymeric substance (EPS) and lipids by Cloacibacterium normanense NK6 using crude glycerol and sludge as substrate. Water Sci. Technol. 77 (9), 2228-2241.

Rodríguez, P., Cerda, A., Font, X., Sánchez, A., Artola, A., 2019. Valorisation of biowaste digestate through solid state fermentation to produce biopesticides from Bacillus thuringiensis. Waste Manage. 93, 63-71.

Rowe, G.E., Margaritis, A., 2004. Bioprocess design and economic analysis for the commercial production of environmentally friendly bioinsecticides from Bacillus thuringiensis HD-1 kurstaki. Biotechnol. Bioeng. 86 (4), 377-388.

Sayed, A.M., Behle, R.W., 2017. Evaluating a dual microbial agent biopesticide with Bacillus thuringiensis var. kurstaki and Beauveria bassiana blastospores. Biocontrol Sci. Tech. 27 (4), 461-474.

Schnepf, E., Crickmore, N., Van Rie, J., Lereclus, D., Baum, J., Feitelson, J., Zeigler, D., Dean, D., 1998. Bacillus thuringiensis and its pesticidal crystal proteins. Microbiol. Mol. Biol. Rev. 62 (3), 775-806.

Sweeting, J., 1997. Project Cost Estimating: Principles and Practice. Institution of Chemical Engineers, Rugby, Warwickshire, UK.

Yezza, A., Tyagi, R., Valero, J., Surampalli, R., 2006. Bioconversion of industrial wastewater and wastewater sludge into Bacillus thuringiensis based biopesticides in pilot fermentor. Bioresour. Technol. 97 (15), 1850-1857.

Yezza, A., Tyagi, R., Valero, J., Surampalli, R., Smith, J., 2004. Scale-up of biopesticide production processes using wastewater sludge as a raw material. J. Ind. Microbiol. Biotechnol. 31 (12), 545-552.

Zhang, W., Zou, H., Jiang, L., Yao, J., Liang, J., Wang, Q., 2015. Semi-solid state fermentation of food waste for production of Bacillus thuringiensis biopesticide. Biotechnol Bioprocess Eng. 20 (6), 1123-1132.

Zouari, N., Jaoua, S., 1999. Production and characterization of metalloproteases synthesized concomitantly with $\delta$-endotoxin by Bacillus thuringiensis subsp. kurstaki strain grown on gruel-based media. Enzyme Microb. Technol. 25 (3-5), 364-371. 